\title{
Kilka uwag w sprawie kontraktualizacji obowiązku świadczenia pracy (zatrudnienie niepracownicze)
}

$\int \begin{aligned} & \text { rofesor Michał Seweryński zawsze koncentrował uwagę na tematach } \\ & \text { rzeczywiście naukowo ważnych. Należało do nich zatrudnienie nie- }\end{aligned}$ pracownicze. Prawo pracy było dla Profesora w konsekwencji „naprawdę” prawem pracy, a nie tylko prawem stosunku pracy, jak to zwyczajowo się przyjmuje. Uważał, że problematyka osób pracujących poza stosunkiem pracy w celach alimentacyjnych, w warunkach zbliżonych do zatrudnienia pracowniczego stanowi zagadnienie niezwykle społecznie i gospodarczo doniosłe, wymagające prawnej regulacji, a wcześniej szeroko zakrojonej dyskusji ze strony ludzi zajmujących się doktryna, by jak najlepiej tę regulację przygotować.

Szczególnego podkreślenia wymaga, że zwracał na ów problem uwagę już w latach osiemdziesiątych, współprzygotowując założenia pod nową regulację kodeksową z zakresu prawa pracy ${ }^{1}$. Było to niezmiernie nowatorskie podejście do problematyki stosunków zatrudnieniowych, biorąc pod uwagę, że wówczas w zasadzie prawie wszyscy pracujący byli zatrudnieni na podstawie stosunku pracy. Do tematu powrócił na V Europejskim Kongresie Prawa Pracy i Zabezpieczenia Społecznego w Leiden w 1996 r. $^{2}$ Zagadnienie musiało być rzeczywiście wyjątkowo ważne, bo Profesor ustanowił je jednym z naczelnych tematów VI Europejskiego Kongresu

* Dr hab., adiunkt w Katedrze Prawa Pracy i Prawa Socjalnego, Wydział Prawa i Administracji Uniwersytetu im. Adama Mickiewicza w Poznaniu, musiala@amu.edu.pl.

${ }_{1}^{1}$ J. Nowacki, M. Pliszkiewicz, J. Rosner, M. Seweryński, W. Szubert, T. Zieliński, Kierunki Reformy Prawa Pracy. Założenia ogólne, Ośrodek Prac Społeczno-Zawodowych NSZZ „Solidarność", Warszawa 1981.

2 M. Seweryński, Prospects for the development of labour law and social security law in central and eastern Europe in the twenty-first century - referat generalny wygłoszony na V Europejskim Kongresie Prawa Pracy i Zabezpieczenia Społecznego w Leiden w 1996 r. 
Prawa Pracy i Zabezpieczenia Społecznego w Warszawie w 1999 r. ${ }^{3}$ Potem nawiązał do niego w artykule Kontraktualizacja stosunków pracy i jej wpływ na ochronę praw pracowników, gdzie pisał: „Szczególnie ważną konsekwencją nadmiernej kontraktualizacji stosunków pracy jest ryzyko zdominowania ich przez czynniki ekonomiczne, kosztem czynników społecznych i moralnych. Oznacza to podporządkowanie polityki pracy polityce gospodarczej, a praw i potrzeb pracowników, prawom pracodawców i potrzebom przedsiębiorstwa. Taki model zdehumanizowanych stosunków pracy wydaje się dziś jeszcze odległą perspektywą ale może się ona stać realną konsekwencją nadmiernej liberalizacji prawa pracy"4.

Jak się wydaje, celnie przewidział naszą rzeczywistość.

Do tej pory w polskiej literaturze prawa pracy pojawiły się zaledwie dwie monografie poświęcone temu tematowi, pozostałe bowiem opracowania mają wybitnie przyczynkarski charakter ${ }^{5}$. Tymczasem zagadnienie nabrało już istotnego znaczenia i można mówić nawet o palącej potrzebie unormowania tego typu pracy. Istnieje zaś odczucie, że doktryna ciągle jeszcze nie zdaje sobie sprawy z ważkości tematu, co więcej, spory w dyskusji nad samym pojmowaniem definicji zatrudnienia niepracowniczego pokazuja że nie do końca panuje zrozumienie w ogóle co do istoty tej problematyki.

1. Zjawisko zarobkującego $\mathrm{w}$ warunkach zbliżonych do pracowniczych jest na rynku pracy czymś powszechnym. Innymi słowy chodzi o osoby, które, działając na własny rachunek, w ramach własnej działalności gospodarczej, osobiście i zasadniczo samodzielnie świadczą pracę na rzecz drugiej strony, z którą pozostają w ekonomicznym uzależnieniu w tym sensie, że otrzymują od niej przeważającą część swojego dochodu. Słusznie o tych pracujących mówi się także jako o „przedsiębiorcach własnej siły roboczej", których kontrahenci zamiast surowej siły roboczej uzyskują ",uszlachetniony półprodukt"6.

Owo zjawisko rozwinęło się w ostatnich kilkunastu latach w Polsce przede wszystkim jako rezultat dążenia pracodawców do unikania rygorów prawnych i wysokich kosztów wiążących się z zatrudnianiem pracow-

${ }^{3}$ A. Supiot, Zatrudnienie pracownicze i zatrudnienie niezależne, [w:] Referaty na VI Europejski Kongres Prawa Pracy i Zabezpieczenia Społecznego, Warszawa, 13-17 września 1999 r., Scholar, Warszawa 1999, s. 137 i nast.

${ }^{4} \mathrm{M}$. Seweryński, Kontraktualizacja stosunków pracy i jej wptyw na ochrone praw pracowników, [w:] Godność człowieka a prawa ekonomiczne i socjalne, Księga Jubileuszowa wydana w piętnastą rocznice ustanowienia Rzecznika Praw Obywatelskich, Warszawa 2003, s. 115.

${ }^{5}$ M. Gersdorf, Prawo zatrudnienia, LexisNexis, Warszawa 2013; A. Musiała, Zatrudnienie niepracownicze, Difin, Warszawa 2011.

6 A. Dylus, Globalizacja. Refleksje etyczne, Zakład Narodowy im. Ossolińskich, Wrocław-Warszawa-Kraków 2005, s. 66-67. 
ników, a więc z zatrudnianiem na podstawie umowy o pracę. Pracodawcy, dokonując przemian w organizacji swojej działalności, rezygnują z zatrudnienia pracowniczego i przechodzą na współpracę $z$ kontrahentami.

Jednakże nie można nie zwrócić uwag na fakt, że opisywane zjawisko stanowi także fragment czy element bardziej złożonych przemian, związanych z przechodzeniem od gospodarki industrialnej, opartej na taylorowsko-fordowskiej organizacji pracy, do gospodarki postindustrialnej. Istota tej nowej gospodarki polega na maksymalizacji elastyczności i innowacyjności produkowania ze względu na wymagania rynku odbiorców - zróżnicowanego i dopasowanego do indywidualnych oczekiwań klientów. To z kolei wymusza taką produkcję, która pozwala skutecznie reagować na zmiany w obrębie różnych sektorów rynku konsumenckiego oraz popytu na specyficzne produkty i nadążać za odpowiednimi zmianami produkcyjnymi. W konsekwencji pojawia się potrzeba reorganizacji systemu pracy, polegającej w dużej mierze na korzystaniu z usług podmiotów zewnętrznych. Ponadto ten typ pracy wychodzi naprzeciw postępującej indywidualizacji życia jednostek, bo pozwala na dość dobre łączenie zarobkowania z innymi zajęciami. Jest on szczególnie ważny w przypadku kobiet, jako że daje niejednokrotnie szansę połączenia pracy zawodowej z opieką nad dzieckiem. Ów sposób zarobkowania stanowi również najbardziej dogodną formę wykonywania wolnych zawodów; realizacja tego typu zawodów najlepiej dokonuje się bowiem w ramach pracy na własnych rachunek, która znakomicie wydobywa istotę wolnego zawodu. Poza tym rozwój owego sposobu aktywności zarobkowej ma również swoje źródło w nowym podejściu do samej pracy, którą traktuje się coraz częściej także jako inwestycję we własną osobę, praca zaś na własny rachunek jest szansą na niezależność, pozwalając na lepsze wykorzystanie swoich umiejętności ${ }^{7}$.

Jak można zauważyć, przedstawiane zjawisko nie ma wyłącznie negatywnej proweniencji. Właściwie $\mathrm{w}$ pierwszej kolejności trzeba byłoby powiedzieć, że jest ono naturalną konsekwencją przemian cywilizacyjnych, szeroko rozumianych przemian gospodarczo-społecznych i ma liczne zalety. Stąd też nie może być postrzegane jako coś zupełnie negatywne, bo nie ma ku temu podstaw. Nadużycia mogą natomiast wystąpić zawsze, także w przypadku zatrudnienia niepracowniczego, i takiej sytuacji należy móc przeciwdziałać.

7 Szerzej m.in. R. Arum, W. Muller, The reemergence of self-employment. A comparative study of self-employment dynamics and social inequality, Princeton University Press, Princeton - Oxford 2004, s. 1-30, a także A. Perulli, Economically dependent/quasi subordinate (parasubordinate) employment: legal, social and economic aspects, Committee on Employment and Social Affairs of the European Parliament and DG Employment and Social Affairs, $19^{\text {th }}$ of June 2003, s. 101-103. 
2. Wyżej opisywane zjawisko $\mathrm{w}$ niniejszym opracowaniu nazywam zatrudnieniem niepracowniczym. Tak też czynił Profesor Michał Seweryński. Stosowanie właśnie tego nazewnictwa na określenie powyższego zjawiska nie jest jednak $\mathrm{w}$ doktrynie powszechne. Zatrudnienie niepracownicze rozumie się bowiem często inaczej. Do zdefiniowana tego typu zatrudnienia podchodzi się przede wszystkim na zasadzie opozycji do zatrudnienia pracowniczego. Wskazuje się zatem, że zatrudnienie, które nie jest zatrudnieniem pracowniczym, pozostaje zatrudnieniem niepracowniczym; i tu zarazem dokonuje się podziału zatrudnienia niepracowniczego na zatrudnienie niepracownicze typu cywilnoprawnego, administracyjnoprawnego, penalnego czy ustrojowoprawnego ${ }^{8}$. Padła również w doktrynie propozycja nieco węższego ujęcia, gdzie wskazuje się, że zatrudnienie niepracownicze to zbiorcze pojęcie dla stosunków prawnych wyodrębnionych ze względu na wspólny element, jakim jest zobowiązanie do świadczenia pracy za wynagrodzeniem, przy czym na warunkach innych niż pracownicze ${ }^{9}$. A zatem tu poza polem zainteresowań znalazłaby się ta część szeroko pojmowanego zatrudnienia niepracowniczego, w której element wynagrodzenia nie występuje. Można wskazać na jeszcze inne podejście do owej kwestii definiowania, a mianowicie na sytuację, gdzie uznano, że pojęcie zatrudnienia niepracowniczego oznacza zatrudnienie 396 osób fizycznych niebędących przedsiębiorcami na podstawie cywilnoprawnych umów o świadczenie usług ${ }^{10}$. Innymi słowy, w tym rozumieniu zatrudnienie niepracownicze utożsamiono zaledwie z pewnym fragmentem cywilnoprawnego zatrudnienia niepracowniczego, bo pozostawiono poza polem zainteresowania te przypadki cywilnoprawnego zatrudnienia, w których osobiście i zasadniczo samodzielnie świadczący pracę, dopełniając zobowiązań publicznoprawnych, staje się przedsiębiorcą.

Tu należy dodać, że pogląd wskazujący, iż zatrudnieniem niepracowniczym jest takie zatrudnienie, które nie stanowi zatrudnienia pracowniczego, wydaje się prima facie bardzo słuszny. Jest to ujęcie proste, oparte, jak wyżej wskazano, na negacji, któremu trudno odmówić cechy prawdziwości. Ową drugą propozycję rozumienia zatrudnienia niepracowniczego można byłoby próbować uzasadniać tym, że tradycyjnie prawo

${ }^{8}$ W. Sanetra, Prawo pracy. Zarys wykładu, t. I, Białystok 1994, s. 54 i nast.; B. Ćwiertniak, Indywidualne prawo pracy. Stosunek pracy, [w:] Prawo pracy, red. K.W. Baran, B. Ćwiertniak, L. Mitrus, A. Sobczyk, Zakamycze, Kraków 2005, s. 171-172.

9 J. Jończyk, Prawo pracy, PWN, Warszawa 1992, s. 102.

10 Z. Hajn, Elastyczność popytu na prace w Polsce. Aspekty prawne, [w:] Elastyczne formy zatrudnienia i organizacji pracy a popyt na prace w Polsce, red. E. Kryńska, IPISS, Warszawa 2003, s. 76. Autor dodaje, że: „W pełniejszym ujęciu zatrudnienie niepracownicze obejmuje także leżące poza prawem pracy stosunki służbowe, jak np. zatrudnienie w policji, siłach zbrojnych itd." 
pracy, nawet to szeroko pojmowane, zajmuje się przede wszystkim zatrudnieniem w celach zarobkowych, w celach alimentacyjnych. Tyle tylko, że jest to ujęcie chyba przestarzałe, bo niby dlaczego z zakresu prawa pracy (prawa ludzi pracy) wyłączać wolontariuszy i tym samym niejako ich w ten sposób „karać” za świadczenie przez nich ochotniczej, darmowej pracy. Z kolei trzecia propozycja wydaje się nietrafiona $\mathrm{w}$ tym aspekcie, że przecież ochrony rzeczywiście potrzebują ci, którzy w pewien sposób cyklicznie, w dłuższym okresie, świadczą pracę osobiście i zasadniczo samodzielnie, jak zaś wiadomo, wówczas spełniają się przesłanki prowadzenia działalności gospodarczej, a więc w sferze prawa publicznego osoby te stają się przedsiębiorcami, co prawda najczęściej jednoosobowymi, ale mimo wszystko przedsiębiorcami. Stąd nie bardzo wiadomo, dlaczego $\mathrm{w}$ owej trzeciej propozycji definiowania tego rodzaju przedsiębiorcy zostali z zakresu definicji zatrudnienia niepracowniczego wyłączeni. Z kolei włączone zostały weń osoby, zawierające sporadycznie umowę cywilnoprawną o świadczenie usług (śmiem twierdzić ",sporadycznie”, ponieważ gdyby czyniły to cyklicznie, wówczas spoczywałby na nich obowiązek z zakresu prawa publicznego, zgłoszenia swojej działalności jako działalności gospodarczej) $)^{11}$.

Zatem właściwie trzeba byłoby rozważyć pierwszą propozycję definiowania zatrudnienia niepracowniczego, jako zatrudnienia, które nie jest zatrudnieniem pracowniczym. W tym miejscu należy powiedzieć, że definicja ta musi mieć, niestety, walor wyłącznie logiczny (i może dydaktyczny $)^{12}$. Ona niczemu bowiem nie służy, poza wskazaniem, że owo zatrudnienie niepracownicze (rozumiane na zasadzie negacji) stanowi zatrudnienie inne niż zatrudnienie pracownicze. Te cztery rodzaje szeroko pojętego zatrudnienia niepracowniczego są bowiem tak różne (a wynika to z odmienności gałęziowej, a przede wszystkim z odmiennego kontekstu aksjologicznego), że ich łączna analiza nie prowadzi do jakiegoś istotniejszego, a właściwie prawie żadnego wspólnego mianownika. Z punktu widzenia bowiem istoty prawa pracy idzie o zatrudnienie w celach alimentacyjnych; ten cel determinuje kształt regulacji owego prawa. W kontekście zatrudnienia niepracowniczego, biorąc pod uwagę ów cel (alimentacyjny), chodzić będzie rzecz jasna wyłącznie o zatrudnienie niepracownicze typu cywilnoprawnego ${ }^{13}$. Co więcej, nie w pełnym zakresie, ponieważ nastąpi

11 Ustawa z dnia 2 lipca 2004 r. o swobodzie działalności gospodarczej, j.t., DzU z 2013 r., nr 672 ze zm.

${ }^{12}$ I chyba tak rzeczywiście jest. Obie definicje są zawarte w podręcznikach.

${ }^{13} \mathrm{~W}$ przypadku niepracowniczego zatrudnienia penalnoprawnego, nie o zatrudnienie w celach zarobkowych chodzi, ale o walor wychowawczy tej pracy, z kolei w przypad$\mathrm{ku}$ niepracowniczego zatrudnienia administracyjnoprawnego oraz ustrojowoprawnego, na plan pierwszy wysuwa się kwestia służby. 
jego ograniczenie do pewnego fragmentu tego rodzaju zatrudnienia. Idzie bowiem nie o wszystkie osoby świadczące pracę na podstawie cywilnoprawnej, ale o te, które czynią to w celach alimentacyjnych, cyklicznie, inaczej rzecz ujmując w okolicznościach zbliżonych do pracowniczych.

Dlatego używając określenia zatrudnienie niepracownicze, winno się mieć na myśli pracujących zarobkowo, w celach alimentacyjnych, osobiście i zasadniczo samodzielnie, pozostających $\mathrm{w}$ warunkach uzależnienia ekonomicznego, czyli tym samym przez dłuższy czas współpracujących z kontrahentem, od którego pochodzi przeważająca część dochodu, inaczej bowiem niejako nie wytworzy się ów stan uzależnienia ekonomicznego - krótko mówiąc $w$ okolicznościach podobnych do zatrudnienia pracowników ${ }^{14}$. Tylko $\mathrm{w}$ ten sposób rozumianych zatrudnionych niepracowniczo można odnosić do stosunku pracy. Zbiorcze ich ujmowanie, a więc na zasadzie negacji wobec zatrudnionych pracowniczo, nie ma waloru poznawczego.

Owszem, wszystkie inne przejawy zatrudnienia niepracowniczego pojmowanego na zasadzie negacji (a więc właśnie administracyjnoprawnego, penalnoprawnego, ustrojowoprawnego i pewnego fragmentu cywilnoprawnego, np. zatrudnienia wolontariuszy), wiążą się rzecz jasna z pracą ludzka, wymagają stosownych regulacji. Jednakże ów cel w postaci zarobku (cel alimentacyjny) w powyższych przypadkach nie jest pierw398 szorzędny (albo nie ma go w ogóle) i, co w konsekwencji bardzo ważne, nie determinuje prawnej regulacji. Ponadto, tak też - słusznie - postrzegają ów problem nazewnictwa francuscy uczeni ${ }^{15}$.

W tym miejscu, niejako na marginesie, należy powiedzieć, że chcąc prawnie ująć wszelkie przejawy ludzkiej pracy, trzeba byłoby stworzyć prawo pracy szeroko rozumiane (jak piszą Francuzi - prawo aktywności zawodowej ${ }^{16}$ ), gdzie wskazano by najpierw na podział zatrudnienia na zatrudnienie alimentacyjne (tu pierwszorzędnym celem jest zarobkowanie o charakterze alimentacyjnym) i niealimentacyjne (zatrudnienie w ramach służby, odbywania kary czy nauki zawodu), co oczywiście nie oznacza, że $\mathrm{w}$ tym ostatnim przypadku nie istnieje zapłata służąca zaspokojeniu potrzeb ${ }^{17}$. W ramach tego pierwszego rodzaju zatrudnienia występowałoby m.in. zatrudnienie pracownicze oraz zatrudnienie niepracownicze (samozatrudnienie zależne), a w ramach owego drugiego mieściłoby się zatrudnienie administracyjnoprawne, ustrojowoprawne, penalnoprawne, wolontarystyczne czy przypadki sporadycznego zawierania umów o świadczenie usług.

${ }^{14}$ Można ich nazwać samozatrudnionymi zależnie.

${ }^{15}$ G. Lyon-Caen, Le droit du travail non salarié, Sirey, Paris 1990.

16 Ibidem.

17 Specjalnie piszę zapłata, ponieważ sam ustawodawca w takich przypadkach wskazuje na uposażenie czy dietę bądź honorarium. 
Stąd jeszcze raz należy przeciwstawić się próbom ujmowania zatrudnienia niepracowniczego szeroko - na zasadzie negacji. W ten sposób idzie się w poprzek motywacjom podejmowania zatrudnienia, a te muszą być brane przez prawodawcę pod uwagę, ponieważ determinują charakter prawnego unormowania danej instytucji, stąd stanowczo nie zgadzam $\mathrm{z}$ kolejnymi tego typu ewentualnymi poglądami wyrażonymi w doktrynie.

3. Przy poszukiwaniu koncepcji unormowania zjawiska zatrudnienia niepracowniczego (samozatrudnienia zależnego), trzeba wziąć pod uwagę następujące możliwości: zgodnie z pierwsza, utrzymano by status quo, czyli uznano bez zmian koncepcję stosunku pracy i pracy na własny rachunek, której częścią jest zatrudnienie niepracownicze ${ }^{18}$; druga miałaby polegać na tym, że stwierdzono by, iż trzeba stworzyć nowy stosunek zatrudnienia - tzw. trzeciego rodzaju - leżący między zatrudnieniem pracowniczym a pracą na własny rachunek (tertium genus); istotą trzeciej byłoby zredefiniowanie i poszerzenie zatrudnienia pracowniczego poprzez szerzej rozumiane podporządkowanie, w konsekwencji czego przy rozróżnianiu zatrudnienia pracowniczego od pracy na własny rachunek brano by pod uwagę kryterium przedsiębrania; z kolei czwarta możliwość miałaby polegać na zbudowaniu pewnego trzonu unormowań ochronnych dla wszystkich pracujących, chodziłoby zaś o zastąpienie ostrego podziału na zatrudnienie pracownicze i pracę na własny rachunek poprzez wskazanie na różne formy aktywności (m.in. zatrudnienie niepracownicze), do których przypisane byłyby zróżnicowane stopnie unormowań ochronnych z zachowaniem owego trzonu dostępnego dla wszystkich (a hard core of social rights applicable to all employment relationships) ${ }^{19}$.

Trzeba odrzucić pierwsze podejście; problem zatrudnienia niepracowniczego nie jest bowiem ani zjawiskiem przejściowym, ani marginalnym, co więcej, rodzi zbyt duże nierówności społeczne, aby pozostawić owo zjawisko poza zainteresowaniem ustawodawcy. W przeciwnym razie istnieje zupełnie realna szansa istotnego dumpingu socjalnego. Co do drugiej możliwości, od razu można wskazać, że zatrudnienie niepracownicze nie tworzy żadnego nowego stosunku prawnego (obok stosunku prawnopracowniczego oraz cywilnoprawnego), ale będąc szczególną postacią pracy na własny rachunek, pozostaje oparte na stosunku cywilnoprawnym. Właściwie rozważać można tylko trzecią i czwartą propozycję

${ }_{18}$ Praca na własny rachunek, to praca nie wymagająca zupełnego jej osobistego świadczenia. A zatem podmiotem pracującym na własny rachunek może być również osoba, która zatrudnia innych, wspierających ją w wykonywaniu pracy. W przypadku zatrudnienia niepracowniczego, które jest fragmentem pracy na własny rachunek - niepracowniczo zatrudniony świadczy pracę zasadniczo samodzielnie, $\mathrm{w}$ bardzo niewielkim stopniu korzystając z pracy innych, pozostając w uzależnieniu ekonomicznym.

${ }_{19}$ Wskazuje na nie A. Perulli, Economically..., s. 101-103. 
unormowania, a więc tę, wedle której w związku z tym, że trudno o wskazanie na odrębność (w postaci trzeciego rodzaju stosunku prawnego) stosunku zatrudnienia niepracowniczo zatrudnionych, należy zmodyfikować stosunek pracy tak, aby móc w jego zakres podmiotowy włączyć świadczących pracę $\mathrm{w}$ ramach tego typu zatrudnienia oraz ową druga opierającą się na założeniu, że możliwe jest wyodrębnienie stosunku zatrudnienia niepracowniczo zatrudnionych (a więc stosunku na tyle różniącego się od stosunku pracy, że niemożliwe staje się włączenie $\mathrm{w}$ ten sposób świadczących pracę w zakres podmiotowy stosunku zatrudnienia pracowniczego), a następnie swoiste dopasowanie dla tegoż stosunku zatrudnienia pewnej ochrony. Wydaje się, że należy opowiedzieć się za tą drugą propozycją. Innymi słowy, chodziłoby o zbudowanie odrębnego od stosunku pracy stosunku zatrudnienia - stosunku zatrudnienia niepracowniczego. Powyższe zaś wynika z faktu głębokich różnic zachodzących co do obu stosunków, tak istotnych, że uniemożliwiają one wtłoczenie przypadku samozatrudnienia zależnego $\mathrm{w}$ ramy stosunku pracy.

Przede wszystkim należy zwrócić uwagę, że zatrudnienie pracownicze ma ów szczególny stan podporządkowania, wyłączny dla tego zatrudnienia, zasadzający się już w sferze faktów, skąd czerpie pracodawcza kompetencja do wydawania poleceńn ${ }^{20}$. Z kolei zatrudnienie niepracownicze to takie, 400 w którym - jak pisał G. Lyon-Caen - występuje podporządkowanie niedokonane [subordination imparfaite], co należy pojmować w ten sposób, iż niepracowniczo zatrudniony nie znajduje się $\mathrm{w}$ tzw. relacji władzy [une relation de pouvoir] - stanie charakterystycznym dla pracownika ${ }^{21}$. Z pracowniczego podporządkowania zakotwiczonego w sferze faktów, a więc wynikającego $\mathrm{z}$ wejścia pracującego $\mathrm{w}$ stan władzy z pracodawca, wypływa możliwość dla tegoż pracodawcy korzystania z sił zatrudnionego - jego energii fizycznej i psychicznej oraz dookreślenia jego obowiązków. Tymczasem w zatrudnieniu niepracowniczym podporządkowanie nie wynika ze sfery faktów, ale wyłącznie ze sfery prawa. Zatem podmiot zatrudniający nie ma tej pewnej, oczywiście prawnie ograniczonej, dowolności korzystania z sił zatrudnionego, a w konsekwencji np. przesuwania go do innej pracy ${ }^{22}$.

${ }^{20}$ Szerzej A. Lyon-Caen, Droit du travail, subordination et décentralisation productive, [w:] Les nouvelles frontières du travail subordonné. Approche pluridisciplinaire, red. H. Petit, N. Thevenot, Édition La Découverte, Paris 2006, s. 92 oraz J.-P. Chauchard, La subordination du salarié, critère du contrat du travail, [w:] La subordination dans le travail. Analyse juridique et sociologique de l'évolution des formes d'autonomie et de contrôle dans la relation de travail, red. J.-P. Chauchard, A.-C. Hardy-Dubernet, La Documentation Française, Paris 2003, s. 22-23.

${ }^{21}$ G. Lyon-Caen, Le droit..., s. 57-58. Szerzej J.-P. Chauchard, La subordination du salarié..., s. 22-23.

${ }^{22}$ Zob. A. Musiała, Prawna problematyka świadczenia pracy przez samozatrudnionego ekonomicznie zależnego, „Monitor Prawa Pracy” 2014, nr 2, s. 69-73. 
Nieprzekonujące wydają się tu opinie, zgodnie z którymi można byłoby tak zmodyfikować kształt współczesnego stosunku pracy, aby możliwe stało się włączenie przypadku samozatrudnienia zależnego w zakres podmiotowy stosunku pracy. Miałoby się to z kolei dokonać poprzez jeszcze większe rozmycie pracowniczego podporządkowania - do tego stopnia, że znaleziono by wspólny mianownik dla pracowniczego podporządkowania i zależności w przypadku samozatrudnionego zależnego. Należy bowiem dostrzec, że pojawienie się podporządkowania autonomicznego, jakkolwiek powoduje wydrążenie podporządkowania ze swej pierwotnej treści, przyznając pracownikowi więcej swobody, to jednak nie uwalnia pracownika z owej relacji władzy-mocy ${ }^{23}$. Rozważania powyższe podsumować można stwierdzając, że jedyną możliwością prawnej regulacji zjawiska zatrudnienia niepracowniczego pozostaje ów czwarty sposób. Zatem kierunek dalszych przemian dzisiejszego prawa pracy powinien iść ku podkreśleniu niepodważalnej pozycji stosunku pracy $\mathrm{w}$ szeroko rozumianym prawie pracy czy może raczej prawie zatrudnienia (prawie aktywności zawodowej) i jednocześnie uznaniu występowania szeregu innych różnorodnych form zatrudnienia. Te zaś alternatywne formy zatrudnienia - $\mathrm{w}$ tym m.in. zatrudnienie niepracownicze - powinny pociagać za sobą swoiste gwarancje ochronne dla wykonawcy pracy świadczonej w ich ramach. Podobnie też wskazywał Profesor Michał Seweryński w 1996 r., twierdząc: „Without questioning the central role of the employment contract in the labour law, alternative forms of employment need to be pursued. Such alternatives forms should seek to link the advantages which derive from the status of »employee« with the flexibility which accompanies other types of contract" 24 .

4. Tak podchodząc do pojmowania stosunku zatrudnienia niepracowniczego dostrzegamy problem zbudowania odrębnej regulacji ochronnej dla tego typu zatrudnienia; choć ową konieczność należy raczej poczytywać za zaletę, ponieważ umożliwia subtelne i precyzyjne dopasowanie unormowań ochronnych. Mając do wyboru: 1) metodę ekspansji prawa pracy oraz 2) metodę tworzenia zupełnie odrębnych unormowań ochronnych dla tego typu zatrudnienia, opowiadam się za tą druga, pozwalającą na precyzyjniejsze tworzenie konkretnych regulacji ochronnych odpowiadających istocie zatrudnienia niepracowniczego ${ }^{25}$. Ów odrębny reżim zmusza do zajęcia stanowiska w sprawie nie tylko zakresu ochrony,

${ }^{23} \mathrm{~V}$. Vannes, Le concept de l'autorité dans les relations de travail, [w:] Le lien de subordination dans le contrat de travail, red.V. Vannes, Bruylant, Bruxelles 2005, s. 38-39.

${ }^{24}$ M. Seweryński, Prospects for the development of labour law..., s. 11-12.

25 Szerzej A. Musiała, Zatrudnienie..., s. 223 i nast. 
jaki miałby zostać przyznany niepracowniczo zatrudnionemu, ale i jego szczegółowego kształtu. Na pewno przedmiotem ochrony w odniesieniu do stosunku zatrudnienia niepracowniczego powinny stać się kwestie: 1) bezpiecznych i higienicznych warunków pracy, 2) trwałości zatrudnienia, 3) przysługującego niepracowniczo zatrudnionemu wynagrodzenia. Jednakże uchylam się od wskazania dokładnego zakresu i kształtu unormowania tejże ochrony, bo bezdyskusyjnie musi być ono poprzedzone szeroko zakrojonymi badaniami naukowymi we współdziałaniu z socjologami i psychologami pracy. Inaczej owo wskazanie będzie miało charakter dyletanctwa naukowego.

Analizując problematykę regulacji ochronnej zatrudnienia niepracowniczego, trzeba wziąć jeszcze pod uwagę, że przy dokonanym wyborze (owej czwartej możliwości) zatrudnienie niepracownicze zacznie stanowić fragment szeroko rozumianego prawa pracy czy prawa zatrudnienia. Ta zaś koncepcja ma zakładać, że dla prawa zatrudnienia buduje się określony katalog unormowań ochronnych, o pewnym ogólnym znaczeniu, wspólny dla wszystkich pracujących. Słusznie pisze M. Gersdorf w tym kontekście o zasadach dla prawa zatrudnienia, wskazując zarazem, że nie jest to łatwe. Jednocześnie M. Gersdorf stara się je wyartykułować ${ }^{26}$. Może pojawić się w tym miejscu niezmiernie ważkie zagadnienie, na które zwrócił uwagę podczas XI Europejskiego Kongresu Prawa Pracy i Zabezpieczenia Społecznego w Dublinie Profesor Michał Seweryński, a mianowicie rozstrzygnięcie, którym $\mathrm{z}$ tych praw (praw zatrudnienia, zasad) - wszystkim, wybranym, czy może jeszcze innym - możliwe byłoby nadanie przymiotu praw podstawowych, praw fundamentalnych w rozumieniu praw niezbywalnych, a więc w sensie praw człowieka.

Konkludując całość niniejszych rozważań należy powiedzieć, że temat zatrudnienia niepracowniczego stanowi zagadnienie bardzo bliskie naukowym zainteresowaniom Profesora Michała Seweryńskiego. Odnosząc się zaś do owego tematu w perspektywie prawa pracy należy powiedzieć, że zatrudnienie niepracownicze winno być odrębną formą zatrudnieniową - jedną z wielu, które tworzą szeroko pojęte prawo pracy (bądź prawo zatrudnienia, prawo aktywności zawodowej), przy czym centralne miejsce byłoby zarezerwowane dla stosunku pracy. Jednocześnie zatrudnienie pracownicze korzystałoby z największego zakresu ochrony, dalej byliby m.in. zależnie samozatrudnieni i jednocześnie korzystający tylko z pewnego zakresu ochrony; w końcu - niezależnie samozatrudnieni poddani surowym regułom prawa cywilnego oraz handlowego i w zasadzie prawie niekorzystający z ochronnej funkcji prawa zatrudnienia.

${ }^{26}$ M. Gersdorf, Prawo..., s. 180 i nast. 


\section{Bibliografia}

Arum R., Muller W., The reemergence of self-employment. A comparative study of self-employment dynamics and social inequality, Princeton University Press, Princeton-Oxford 2004.

Chauchard J.-P., La subordination du salarié, critère du contrat du travail, [w:] La subordination dans le travail. Analyse juridique et sociologique de l'évolution des formes d'autonomie et de contrôle dans la relation de travail, red. J.-P. Chauchard, A.-C. Hardy-Dubernet, La Documentation Française, Paris 2003.

Ćwiertniak B., Indywidualne prawo pracy. Stosunek pracy, [w:] Prawo pracy, red. K.W. Baran, B. Ćwiertniak, L. Mitrus, A. Sobczyk, Zakamycze, Kraków 2005.

Dylus A., Globalizacja. Refleksje etyczne, Zakład Narodowy im. Ossolińskich, Wrocław-Warszawa-Kraków 2005.

Gersdorf M., Prawo zatrudnienia, LexisNexis, Warszawa 2013.

Musiała A., Zatrudnienie niepracownicze, Difin, Warszawa 2011.

Hajn Z., Elastyczność popytu na prace w Polsce. Aspekty prawne, [w:] Elastyczne formy zatrudnienia i organizacji pracy a popyt na prace w Polsce, red. E. Kryńska, IPISS, Warszawa 2003.

Jończyk J., Prawo pracy, PWN, Warszawa 1992.

Lyon-Caen A., Droit du travail, subordination et décentralisation productive, [w:] Les nouvelles frontières du travail subordonné. Approche pluridisciplinaire, red. H. Petit, N. Thevenot, Édition La Découverte, Paris 2006.

Lyon-Caen G., Le droit du travail non salarié, Sirey, Paris 1990.

Musiała A., Prawna problematyka świadczenia pracy przez samozatrudnionego ekonomicznie zależnego, „Monitor Prawa Pracy” 2014, nr 2.

Nowacki J., Pliszkiewicz M., Rosner J., Seweryński M., Szubert W., Zieliński T., Kierunki Reformy Prawa Pracy. Założenia ogólne, Ośrodek Prac Społeczno-Zawodowych NSZZ „Solidarność", Warszawa 1981.

Perulli A., Economically dependent/quasi subordinate (parasubordinate) employment: legal, social and economic aspects, Committee on Employment and Social Affairs of the European Parliament and DG Employment and Social Affairs, 19 $9^{\text {th }}$ of June 2003.

Sanetra W., Prawo pracy. Zarys wykładu, t. I, Białystok 1994.

Seweryński M., Kontraktualizacja stosunków pracy i jej wpływ na ochronę praw pracowników, [w:] Godność człowieka a prawa ekonomiczne i socjalne, Księga Jubileuszowa wydana w piętnasta rocznice ustanowienia Rzecznika Praw Obywatelskich, Warszawa 2003.

Seweryński M., Prospects for the development of labour law and social security law in central and eastern Europe in the twenty-first century - referat generalny wygłoszony na V Europejskim Kongresie Prawa Pracy i Zabezpieczenia Społecznego w Leiden w 1996 r.

Supiot A., Zatrudnienie pracownicze i zatrudnienie niezależne, [w:] Referaty na VI Europejski Kongres Prawa Pracy i Zabezpieczenia Społecznego, Warszawa, 13-17 września 1999 r., Scholar, Warszawa 1999.

Vannes V., Le concept de l'autorité dans les relations de travail, [w:] Le lien de subordination dans le contrat de travail, red. V. Vannes, Bruylant, Bruxelles 2005. 


\title{
Remarks on the Contractualisation of the Duty to Perform the Work (Non-employee Work)
}

\begin{abstract}
Summary
Professor Michał Seweryński has always focused on subjects that he considered really scientifically important. As his vision was wider and more profound, non-employment contracts were one of the topics he concentrated on. Therefore, the Professor perceived labour law as the "real" labour law and not just a law concerning employment relations, as it is commonly understood. Professor was of the opinion that the issues concerning people working outside the employment framework, in conditions similar to those of employment, are matters of profound social and economic importance which require better regulation preceded by a widespread discussion on the matter in order to achieve the best possible end result.
\end{abstract}

